\title{
Pengaruh Kinerja Keuangan pada Belanja Daerah dan Pertumbuhan Ekonomi dan Implikasinya pada Indeks Pembangunan Manusia
}

\author{
Luh Dini Yasintha Dwiyandari ${ }^{1}$ \\ I Dewa Nyoman Badera ${ }^{2}$
}

\author{
${ }^{1}$ Fakultas Ekonomi dan Bisnis Universitas Udayana (Unud), Bali, Indonesia \\ email: ddini.yasinthaa@yahoo.co.id / Telp: +6281547124301 \\ ${ }^{2}$ Fakultas Ekonomi dan Bisnis Universitas Udayana (Unud), Bali, Indonesia
}

\begin{abstract}
ABSTRAK
Peningkatan Indeks Pembangunan Manusia (IPM), ketepatan alokasi belanja daerah dan tingginya pertumbuhan ekonomi merupakan gambaran hasil kinerja pemerintah dalam mensejahterakan rakyatnya. Tercapainya tujuan pembangunan manusia yang tercermin pada IPM sangat tergantung komitmen pemerintah sebagai penyedia sarana penunjang. Kinerja keuangan yang semakin meningkat, diduga tidak selalu mampu mendorong pertumbuhan ekonomi, serta ketepatan alokasi belanja daerah dan peningkatan Indeks Pembangunan Manusia. Penelitian ini bertujuan untuk mengetahui pengaruh kinerja keuangan daerah pada pertumbuhan ekonomi dan belanja daerah terhadap Indeks Pembangunan Manusia. Sampel dalam penelitian ini adalah 8 Kabupaten dan 1 Kota di Provinsi Bali dengan objek penelitian yaitu kinerja keuangan daerah, belanja daerah, pertumbuhan ekonomi, dan Indeks Pembangunan Manusia tahun 2011-2015. Penentuan sampel dilakukan dengan menggunakan metode nonprobabilitas dan teknik sampling jenuh. Penelitian ini menggunakan teknik analisis regresi linear berganda. Hasil penelitian menunjukkan bahwa kinerja keuangan tidak berpengaruh pada pertumbuhan ekonomi, sedangkan kinerja keuangan berpengaruh positif pada belanja daerah dan indeks pembangunan manusia. Hasil pengujian juga menunjukkan bahwa pertumbuhan ekonomi tidak berpengaruh pada indeks pembangunan manusia namun belanja daerah berpengaruh positif pada indeks pembangunan manusia. Hasil pengujian mediasi menunjukkan bahwa belanja daerah mampu memediasi hubungan antara kinerja keuangan terhadap indeks pembangunan manusia, sedangkan pertumbuhan ekonomi tidak dapat memediasi pengaruh kinerja keuangan daerah terhadap indeks pembangunan manusia.
\end{abstract}

Kata kunci: Kinerja keuangan, pertumbuhan ekonomi, belanja daerah, indeks pembangunan manusia

\begin{abstract}
Increasing Human Development Index, the accuracy of local expenditure allocation and high economic growth is a picture of government performance in the prosperity of its people. The achievement of human development goals reflected in Human Development Index is highly dependent on government commitment as a provider of supporting facilities. Improved financial performance, allegedly not always able to encourage economic growth, as well as the accuracy of local expenditure allocations and improvement of the Human Development Index. This study aims to determine the effect of regional financial performance on economic growth and regional spending on the Human Development Index. The sample in this research are 8 regencies and 1 city in Bali Province with research object that is regional finance performance, regional expenditure, economic growth, and Human Development Index year 2011-2015. Sample determination was done by using nonprobability method and saturated sampling technique. This research uses multiple linear regression analysis technique. The results show that financial performance has no effect on economic growth, while financial performance has a positive effect on regional expenditure and human development index. The test results also show that economic growth has no effect on the human development index but local spending has a positive effect on the human development index. The results of mediation testing indicate
\end{abstract}


that regional expenditure is able to mediate the relationship between financial performance on the human development index, while economic growth can not mediate the effect of local financial performance on human development index.

Keywords: Financial performance, economic growth, regional spending, human development index

\section{PENDAHULUAN}

Keberhasilan pembangunan khususnya pembangunan manusia dapat dinilai secara parsial dengan melihat seberapa besar permasalahan yang paling mendasar dimasyarakat tersebut dapat teratasi. Otonomi daerah membuat pemerintah daerah diberi mandat berupa tugas-tugas yang harus dijalankan. Tercapainya tujuan pembangunan manusia yang tercermin pada Indeks Pembangunan Manusia (IPM) sangat tergantung komitmen pemerintah sebagai penyedia sarana penunjang. IPM (Indeks Pembangunan Manusia) merupakan salah satu indikator tingkat kemiskinan di suatu wilayah yang menggambarkan kombinasi antara tingkat kesehatan, tingkat pendidikan dan standar hidup layak (dengan ukuran ketimpangan antar wilayah). Dalam penelitian ini digunakan IPM sebagai acuan untuk menentukan tingkat kemiskinan dalam bentuk ranking kemiskinan suatu daerah.

Tabel 1.

IPM Kabupaten/Kota di Provinsi Bali Tahun 2010 - 2015

\begin{tabular}{lllllll}
\hline Kabupaten/Kota & $\mathbf{2 0 1 0}$ & $\mathbf{2 0 1 1}$ & $\mathbf{2 0 1 2}$ & $\mathbf{2 0 1 3}$ & $\mathbf{2 0 1 4}$ & $\mathbf{2 0 1 5}$ \\
\hline Jembrana & 72.69 & 73.18 & 73.62 & 74.29 & 74.38 & 74.62 \\
Tabanan & 74.57 & 75.24 & 75.55 & 76.19 & 76.24 & 76.55 \\
Badung & 75.02 & 75.35 & 75.69 & 76.37 & 77.35 & 77.69 \\
Gianyar & 72.73 & 73.43 & 74.49 & 75.02 & 75.43 & 76.49 \\
Klungkung & 70.54 & 71.02 & 71.76 & 72.25 & 72.32 & 73.76 \\
Bangli & 70.71 & 71.42 & 71.80 & 72.28 & 72.42 & 72.80 \\
Karangasem & 66.42 & 67.07 & 67.83 & 68.47 & 68.97 & 69.43 \\
Buleleng & 70.69 & 71.12 & 71.93 & 72.54 & 72.82 & 72.93 \\
Denpasar & 77.94 & 78.31 & 78.80 & 79.41 & 79.91 & 80.08 \\
BALI & 72.28 & 72.84 & 73.49 & 74.11 & 74.84 & 75.49 \\
Nasional & 72,27 & 72,64 & 73,29 & 73,81 & 74,24 & 75,89 \\
\hline
\end{tabular}

Sumber: BPS Provinsi Bali, 2016 
Pada tabel 1. terlihat bahwa nilai IPM Provinsi Bali cenderung mengalami peningkatan dari 72,28 pada tahun 2010 menjadi 75,49 pada tahun 2015, walaupun tren IPM Bali meningkat dari tahun ke tahun tetapi masih ada beberapa daerah yang memiliki nilai IPM yang berada di bawah rata - rata IPM Provinsi. Selain itu jika di bandingkan dengan IPM nasional IPM Bali pernah berada di bawah IPM nasional yaitu pada tahun 2015 IPM Provinsi Bali sebesar 75,49 sedangkan IPM nasional sebesar 75,89. Hal ini juga mengindikasikan bahwa IPM Provinsi Bali belum mampu mencapi peningkatan IPM yang maksimal karena pernah berada di bawah IPM Nasional, hal ini mengindikasikan bahwa penelitian terkait IPM khususnya di Provinsi Bali, sangat penting untuk di kaji kembali. Untuk itu peneliti meyakini bahwa dengan meningkatkan jumlah PAD yang diterima dan pemberian dana perimbangan yang lebih besar kepada daerah dari pemerintah pusat akan dapat mendorong peningkatan yang berkelanjutan bagi IPM di daerah, apalagi jika penerimaan daerah tersebut dialokasikan kepada belanja langsung yang bersentuhan langsung dengan ketiga komponen IPM (Adi, 2007).

Salah satu unsur yang paling penting dalam penyelenggaraan pemerintahan dan pembangunan didaerah cara pengelolaan keuangan daerah dengan baik, sehingga sesuai dengan aspirasi pembangunan dan tuntutan masyarakat. Kinerja pemerintah yang sering dijadikan acuan dalam melihat tingkat kesejahteraan masyarakat salah satunya kinerja keuangan. Alat ukur untuk menilai kinerja keuangan pemerintah cukup banyak, diantaranya adalah analisis rasio keuangan terhadap Anggaran Pendapatan dan Belanja Daerah (APBD). 
Luh Dini Yasintha Dwiyandari dan I Dewa Nyoman Badera. Pengaruh ...

Kinerja merupakan pencapaian atas apa yang direncanakan, baik oleh pribadi maupun organisasi. Apabila pencapaian sesuai dengan yang direncanakan, maka kinerja yang dilakukan terlaksana dengan baik. Analisis kinerja keuangan APBD dilakukan dengan membandingkan hasil yang dicapai dari satu periode dengan periode sebelumnya sehingga dapat diketahui bagaimana kecenderungan yang terjadi. Kinerja keuangan dalam penelitian diukur dengan menggunakan rasio keuangan APBD, antara lain: rasio kemandirian untuk menilai tingkat kemandirian keuangan daerah dalam membiayai penyelenggaraan otonomi daerah (Halim, 2007:232).

Beberapa peneliti yang melakukan penelitian mengenai pengaruh kinerja keuangan berupa rasio kemandirian, rasio efektivitas, dan rasio efisiensi terhadap Indeks Pembangunan Manusia, memberikan hasil yang bervariasi. Hasil dari penelitian Hamzah (2008) adalah rasio kemandirian dan rasio efisiensi berpengaruh positif secara signifikan terhadap Indeks Pembangunan Manusia, sedangkan rasio efektifitas tidak berpengaruh secara signifikan terhadap Indeks Pembangunan Manusia. Penelitian Maiputra (2011) menunjukkan rasio kemandirian berpengaruh secara positif signifikan terhadap pertumbuhan ekonomi dan Indeks Pembangunan Manusia. Penelitian Kaliti (2011) menunjukkan rasio kemandirian dan efektivitas tidak berpengaruh positif terhadap Indeks Pembangunan Manusia, sedangkan rasio efisiensi tidak berpengaruh negatif terhadap Indeks Pembangunan Manusia. Penelitian Annisa (2011) menunjukkan bahwa rasio kemandirian, efektivitas dan efisiensi berpengaruh positif signifikan terhadap Indeks Pembangunan Manusia. 
Penelitian-penelitian terdahulu telah membuktikan adanya inkonsistensi hasil penelitian. Inkonsistensi hasil penelitian menunjukkan bahwa diindikasikan terdapat prediktor lain yang dapat mempengaruhi secara langsung maupun tak langsung hubungan antara kinerja keuangan daerah terhadap Indeks Pembangunan Manusia. Dalam penelitian ini, diindikasikan bahwa pertumbuhan ekonomi dan Belanja Daerah dapat menjadi mediasi antara kinerja keuangan terhadap kemiskinan.

Pertumbuhan ekonomi merupakan ukuran utama keberhasilan pembangunan, dan hasil pertumbuhan ekonomi dapat pula dinikmati oleh masyarakat sampai yang paling bawah, baik dengan sendirinya maupun dengan campur tangan pemerintah (Hamzah, 2008). Pertumbuhan ekonomi yang tinggi merupakan gambaran hasil kinerja pemerintah dalam mensejahterakan rakyatnya. Pertumbuhan ekonomi selalu menjadi indikator tingkat kesejahteraan penduduk suatu daerah atau Negara. Dengan tercapainya pertumbuhan ekonomi yang tinggi dan pemerataan pendapatan, berarti secara langsung maupun tidak langsung akan mengurangi serta menurunkan tingkat kemiskinan (Hamzah, 2008).

Penelitian terdahulu mengenai pengaruh pertumbuhan ekonomi terhadap kemiskinan dilakukan oleh Siregar dan Wahyuniarti (2007), Ginting dan Rasbin (2008) dimana hasilnya menunjukkan bahwa pertumbuhan ekonomi berpengaruh positif signifikan terhadap tingkat kemiskinan. Sedangkan penelitian Hamzah (2008), Prastyo (2010), Katili (2011), Annisa (2011) menunjukkan bahwa pertumbuhan ekonomi berpengaruh negatif terhadap Indeks Pembangunan Manusia. 
Rangka mewujudkan daerah dengan kualitas manusianya yang tinggi, pemerintah menggunakan APBD-nya utuk membiayai pembangunan di sektor tersebut (Maryani, 2012). Secara spesifik, pemerintah daerah harus bisa mengalokasikan belanja daerah melalui belanja pembangunan di sektor-sektor pendukung untuk meningkatkan IPM misalnya yang tercermin pada realisasi belanja daerah untuk bidang pendidikan, kesehatan dan ekonomi. Pemerintah mengalokasikan dana untuk peningkatan pelayanan dalam bentuk alokasi belanja daerah yang nantinya diharapkan dapat meningkatkan kualitas hidup masyarakatnya (Sarkoro dan Zulfikar, 2016). Johana (2011) menyatakan bahwa belanja pemerintah disektor pendidikan dan kesehatan akan dapat memengaruhi kemiskinan jika belanja tersebut dilakukan dalam rangka peningkatan kualitas pembangunan manusia. Badrudin dan Khasanah (2011) menyatakan bahwa variabel belanjapemerintah di Provinsi DIY pada sektor pendidikan berpengaruh tidak signifikan terhadap pembangunan manusia di provinsi

Maryani (2012) menyatakan bahwa belanja pemerintah sektor pendidikan, belanja pemerintah sektor kesehatan dan jumlah penduduk miskin berpengaruh posistif terhadap IPM. Meskipun berpengaruh positif belanja pemerintah sektorpendidikan dan kesehatan masih berpengaruh kecil terhadap IPM, hal ini menandakan bahwa belanja untuk sektor tersebut belum optimal baik daripenggunaannya dan alokasinya.

Hasil analisis kinerja keuangan daerah merupakan informasi penting terutama untuk membuat kebijakan dalam pengelolaan keuangan daerah dan menilai keberhasilan pemerintah daerah dalam mengelola keuangannya. 
Pengukuran kinerja keuangan daerah juga sangat penting untuk menilai akuntabilitas pemerintah daerah dalam memberikan pelayanan kepada publik dengan baik (Dewi, 2007). Oleh karena itu, analisa kinerja keuangan daerah baik terhadap perhitungan pendapatan maupun belanja daerah perlu dilakukan untuk mendorong atau memotivasi pemerintah untuk meningkatkan kinerjanya dalam menghadapi otonomi daerah. Akibat meningkatnya kinerja keuangan maka secara langsung maupun tidak langsung dapat meningkatkan pertumbuhan ekonomi dan belanja daerah sehingga mempengaruhi tingkat indeks pembangunan manusia.

Tujuan dari penelitian ini adalah sebagai berikut: 1) Untuk mengetahui pengaruh Kinerja Keuangan pada Indeks Pembangunan Manusia di Pemerintah Provinsi Bali; 2) Untuk mengetahui pengaruh Kinerja Keuangan Daerah pada Pertumbuhan Ekonomi di Pemerintah Provinsi Bali; 3) Untuk mengetahui pengaruh Kinerja Keuangan Daerah pada Belanja Daerah di Pemerintah Provinsi Bali; 4) Untuk mengetahui pengaruh Belanja Daerah pada Indeks Pembangunan Manusia di Pemerintah Provinsi Bali; 5) Untuk mengetahui pengaruh Pertumbuhan Ekonomi pada Indeks Pembangunan Manusia di Pemerintah Provinsi Bali; 6) Untuk mengetahui kemampuan Pertumbuhan Ekonomi memediasi pengaruh Kinerja Keuangan Daerah pada Indeks Pembangunan Manusia; 7) Untuk Mengetahui kemampuan Belanja Daerah memediasi pengaruh Kinerja Keuangan Daerah pada Indeks Pembangunan Manusia.

Penelitian ini dapat memberikan gambaran, pemahaman, dan wawasan yang lebih luas mengenai pengaruh kinerja keuangan daerah terhadap belanja daerah dan pertumbuhan ekonomi serta implikasinya pada indeks pembangunan 
Luh Dini Yasintha Dwiyandari dan I Dewa Nyoman Badera. Pengaruh ...

manusia. Agency theory mengasumsikan bahwa prinsipal dan agen termotivasi oleh kepentingannya sendiri, dan seringkali kepentingan antara keduanya berbenturan (Ikhsan dan Ishak, 2005:56). Perbedaan kepentingan ini masingmasing pihak berusaha memperbesar keuntungan bagi diri sendiri. Usulan yang diajukan oleh eksekutif (agen) memiliki muatan mengutamakan kepentingan eksekutif. Sesuai dengan yang dikemukakan oleh Moe (1984) yang menjelaskan konsep ekonomika organisasi sektor publik dengan menggunakan teori keagenan, di pemerintahan terdapat suatu keterkaitan dalam kesepakatan - kesepakatan principal-agent yang dapat ditelusuri melalui proses anggaran: pemilih-legislatur, legislatur-pemerintah, menteri keuangan-pengguna anggaran, perdana menteribirokrat, dan pejabat-pemberi pelayanan.

Penyusunan APBD diawali dengan terbentuknya kesepakatan antara eksekutif dan legislatif tentang Kebijakan Umum APBD dan Prioritas dan Plafon Anggaran yang akan menjadi pedoman untuk penyusunan anggaran pendapatan dan anggaran belanja. Setelah itu, eksekutif akan membuat rancangan APBD sesuai dengan Kebijakan Umum APBD dan Prioritas dan Plafon Anggaran yang kemudian diberikan kepada legislatif untuk dipelajari dan dibahas bersama-sama sebelum ditetapkan sebagai Peraturan Daerah (Perda). Dalam sudut pandang teori keagenan, hal ini merupakan sebuah bentuk kontrak (incomplete contract), yang menjadi alat bagi legislatif untuk mengawasi pelaksanaan anggaran oleh eksekutif.

Teori fiscal federalism merupakan teori yang dikembangkan oleh Hayek (1945), Musgrave (1959) dan Oates (1972). Teori fiscal federalism menyatakan 
bahwa pertumbuhan ekonomi dicapai dengan desentralisasi fiskal melalui pelaksanaan otonomi daerah. Teori tentang fiscal federalism menurut Oates (1999) bahwa untuk barang atau jasa publik tertentu seperti barang publik daerah, desentralisasi dapat meningkatkan efisiensi dan akuntabilitas alokasi sumber daya.

Desentralisasi fiskal dikatakan menawarkan sejumlah manfaat bagi tata kelola sektor publik, termasuk pertumbuhan, akuntabilitas dan responsivitas para pejabat pemerintah terhadap tuntutan lokal dan kebutuhan (Amagoh \& Amin, 2012). Desentralisasi fiskal memberikan struktur insentif yang lebih besar bagi pemerintah untuk menjadi lebih efisien dalam mengalokasikan sumber daya fiskal, namun itu tidak selalu mengarah pada pertumbuhan yang kuat karena meningkatnya kesenjangan antar daerah terutama di tingkat kapasitas pembangunan dan sumber daya (Tirtosuharto, 2010).

Pengelolaan daerah yang dilakukan secara ekonomis, efisien, dan efektif akan mendorong pertumbuhan ekonomi (Hamzah, 2008). Pengelolaan daerah dapat tercermin melalui kinerja keuangan daerah dalam APBD. Hasil penelitian Hamzah (2008) menunjukkan bahwa kinerja keuangan yang meliputi rasio kemandirian, yang menggambarkan kemampuan pemerintah daerah dalam mengelola dan membiayai pembangunan daerahnya masing-masing menunjukkan adanya pengaruh positif dan secara statistik signifikan terhadap pertumbuhan ekonomi. Hal ini menunjukkan bahwa daerah telah mampu mengurangi ketergantungannya terhadap bantuan keuangan dari pemerintah pusat. Dengan semakin mandiri daerah tersebut, maka pertumbuhan ekonomi di daerah tersebut dapat mengalami peningkatan. 
Luh Dini Yasintha Dwiyandari dan I Dewa Nyoman Badera. Pengaruh ...

Pertumbuhan pendapatan, mengukur seberapa besar kemampuan pemerintah daerah untuk mempertahankan dan meningkatkan keberhasilan kinerja keuangannya dari periode ke periode berikutnya. Dalam penelitian ini, menekankan pada pertumbuhan pendapatan daerah. Komaidi (2006), menemukan bahwa penerimaan pemerintah berpengaruh positif dan secara ststistik signifikan dalam mempengaruhi suatu perekonomian. Apabila terjadi kenaikan penerimaan pemerintah baik dari pajak maupun hibah akan menyebabkan kenaikan pertumbuhan ekonomi (Komaidi, 2006). Berdasarkan hal tersebut maka hipotesis yang diajukan pada penelitian ini adalah.

$\mathrm{H}_{1}$ : Rasio kemandirian berpengaruh positif pada pertumbuhan ekonomi di Pemerintah Provinsi Bali.

Rasio kemandirian daerah mencerminkan keadaan otonomi suatu daerah yang diukur dengan besarnya PAD terhadap jumlah total pendapatan daerah. Rasio kemandirian menggambarkan ketergantungan daerah terhadap sumber dana ekstern. Semakin tinggi rasio kemandirian mengandung arti bahwa tingkat ketergantungan daerah terhadap bantuan pihak ekstern (terutama pemerintah pusat dan provinsi) semakin rendah, dan demikian pula sebaliknya. Kemiskinan meupakan ketidakmampuan memenuhi standar minimum kebutuhan dasar yang meliputi kebutuhan makan maupun non makan (BPS, 2008). Kemiskinan juga merupakan salah satu unsur suatu perekonomian yang sangat penting dan harus mendapat perhatian lebih dari pemerintah. Pertumbuhan ekonomi akan mempengaruhi tingkat kemiskinan suatu daerah, karena dengan meningkatnya pertumbuhan ekonomi, maka tingkat kemiskinan suatu daerah akan menurunkan. 
Hamzah (2008) dalam penelitiannya yang berjudul analisa kinerja keuangan terhadap pertumbuhan ekonomi, pengangguran dan kemiskinan menunjukkan bahwa variabel kinerja keuangan antara lain rasio kemandirian, rasio efektivitas dan rasio efisiensi secara langsung berpengaruh negatif terhadap kemiskinan. Berdasarkan uraian diatas, maka diajukan hipotesis sebagai berikut.

$\mathrm{H}_{2}$ : Rasio kemandirian berpengaruh negatif pada indeks pembangunan manusia di Pemerintah Provinsi Bali.

Pengaruh kinerja keuangan terhadap belanja daerah banyak dilakukan, sebagai contoh penelitian yang pernah dilakukan oleh Bambang Prakosa (2004), Abdullah dan Halim (2004) menyatakan kinerja keuangan akan mempengaruhi Anggaran Belanja Pemerintah Daerah dikenal dengan nama tax spend hyphotesis. Dalam hal ini pengeluaran Pemerintah Daerah akan disesuaikan dengan perubahan dalam penerimaan Pemerintah Daerah atau perubahan pendapatan terjadi sebelum perubahan pengeluaran.

Kebijakan desentralisasi ditujukan untuk mewujudkan kemandirian daerah, sehingga diharapakn kinerja daerah meningkat. Kemampuan daerah untuk menyediakan pendanaan yang berasal dari daerah sangat tergantung pada kemampuan merealisasikan potensi ekonomi tersebut menjadi bentuk-bentuk kegiatan ekonomi yang mampu menciptakan perguliran dana untuk pembangunan daerah yang berkelanjutan. Abdullah dan Halim (2004) menemukan bahwa kinerja keuangan memiliki pengaruh positif terhadap belanja daerah. PAD memiliki peran yang cukup signifikan dalam menentukan kemampuan daerah untuk melakukan aktivitas pemerintah dan program-program pembangunan. Pemerintah mempunyai kewajiban untuk meningkatkan taraf kesejahteraan rakyat 
serta menjaga dan memelihara ketentraman dan ketertiban masyarakat (Puspita Sari, 2010). Berdasarkan hal tersebut maka hipotesis yang diajukan pada penelitian ini adalah.

$\mathrm{H}_{3}$ : Kinerja keuangan berpengaruh positif pada belanja daerah di Pemerintah Provinsi Bali

Pertumbuhan ekonomi merupakan indikator yang sangat penting dalam melihat kemajuan pembangunan ekonomi di suatu daerah. Pertumbuhan ekonomi menunjukkan sejauh mana aktivitas perekonomian akan menghasilkan tambahan pendapatan masyarakat pada suatu periode tertentu (Susanti, 2007). World Bank (2007) mengemukakan bahwa pertumbuhan ekonomi adalah satu-satunya penggerak terpenting bagi upaya penanggulangan kemiskinan. Karena itu, upaya menjadikan pertumbuhan ekonomi bermanfaat bagi penduduk miskin membutuhkan upaya menciptakan pertumbuhan sekaligus memastikan bahwa pertumbuhan ini dapat dirasakan oleh penduduk miskin.

Pemerintah Daerah dipandang perlu memerhatikan pertumbuhan ekonomi sebagai sebuah instrumen dalam mendorong pembangunan ekonomi agar pada akhirnya dapat mencapai tujuan penanggulangan kemiskinan yang efektif dan meningkatkan kesejahteraan (welfare) masyarakat. Pertumbuhan ekonomi dapat menjadi variabel yang sangat penting bagi upaya menanggulangi kemiskinan di daerah, khususnya Provinsi Bali. Dengan adanya pertumbuhan pendapatan riil masyarakat maka akan terjadi peningkatan daya beli masyarakat. Daya beli masyarakat adalah aspek penting agar masyarakat mampu memenuhi kebutuhan hidupnya, utamanya memenuhi kebutuhan minimal standar hidup layak (basic needs). Apabila daya beli masyarakat meningkat akibat adanya kenaikan 
pendapatan riil masyarakat maka tentu pengeluaran masyarakat dapat lebih meningkat dan lebih sejahtera. Sebaliknya, jika daya beli masyarakat lemah akibat rendahnya pendapatan riil masyarakat maka akan menyebabkan masyarakat sulit memenuhi standar minimal hidup layak. Berdasarkan uraian diatas, maka diajukan hipotesis sebagai berikut:

$\mathrm{H}_{4}$ : Pertumbuhan ekonomi berpengaruh negatif pada indeks pembangunan manusia di Pemerintah Provinsi Bali.

Secara umum belanja daerah dapat diartikan sebagai jumlah dana yang dikeluarkan pemerintah daerah dengan tujuan perkembangan kegiatan dalam perekonomian yang menyebabkan barang dan jasa yang diproduksi dalam masyarakat bertambah dan kemakmuran masyarakat meningkat. Menurut Saragih (2003) Peningkatan belanja daerah harus berdampak pada perekonomian daerah. Sidik (2002) menegaskan bahwa keberhasilan peningkatan belanja daerah hendaknya tidak hanya diukur dari jumlah yang diterima, tetapi juga diukur dengan perannya untuk mengatur perekonomian masyarakat agar dapat lebih berkembang, yang pada gilirannya dapat meningkatkan kesejahteraan masyarakat di daerah. Daerah yang pertumbuhan ekonominya positif mempunyai kemungkinan mendapatkan kenaikan belanja daerah. Dari perspektif ini seharusnya pemda lebih berkonsentrasi pada pemberdayaan kekuatan ekonomi lokal untuk menciptakan pertumbuhan ekonomi daripada sekedar mengeluarkan produk perundangan terkait dengan pajak ataupun retribusi (Adi, 2007). Peningkatan PAD secara signifikan menunjukkan kemampuan daerah dalam memenuhi kebutuhannya serta memakmurkan masyarakatnya. 
Semakin tinggi belanja daerah suatu daerah, maka tingkat ketergantungan fiskal daerah tersebut kepada pusat semakin berkurang. Selanjutnya daerah lebih leluasa dan fleksibel dalam merencanakan alokasi anggaran sesuai dengan agenda ekonominya. Melalui belanja rutin, belanja pembangunan/infrastruktur, ataupun belanja lainnya, belanja daerah sebagai sumber pembiayaan daerah diharapkan mampu menciptakan sejumlah aktivitas ekonomi baru dalam masyarakat. Dengan meningkatnya aktivitas ekonomi pada masyarakat, akan terjadi peningkatan jumlah output barang dan/ atau jasa yang diikuti pula dengan meningkatnya jumlah uang beredar dari segi pembelanjaan yang dilakukan oleh pemerintah daerah. Selanjutnya hal tersebut akan meningkatkan tingkat kesejahteraan masyarakat. Berdasarkan hal tersebut maka hipotesis yang diajukan pada penelitian ini adalah.

$\mathrm{H}_{5}$ : Belanja daerah berpengaruh positif pada indeks pembangunan manusia di Pemerintah Provinsi Bali.

Belanja daerah merupakan kegiatan konsumsi yang dilakukukan oleh pemerintah yang dapat meningkatkan kesejahteraan masyarakat. Dasar pemikirannya dimana pengeluaran pemerintah dapat menstimulus perimintaan dan penawaran terhadap barang dan jasa sehingga akan meningkatkan kegiatan ekonomi masyarakat dan meningkatkan investasi baik swasta, pemerintah maupun penanam modal asing. Aktivitas ekonomi yang meningkat sebagai dampak dari investasi dapat menciptakan kesempatan kerja yang pada akhirnya dapat meningkatkan pendapatan dan kesejahteraan masyarakat. Sehingga kegiatan konsumsi pemerintah melalui belanja langsung tidak hanya dapat berguna bagi aparatur pemerintah namun juga melibatkan masyarakat sehingga meningkatkan 
kesejahteraan masyarakat. Studi yang menunjukkan hubungan positif antara belanja daerah dan kinerja keuangan diantaranya: Ram (1986) menemukan hubungan positif antara pengeluaran pemerintah dengan pertumbuhan ekonomi. Diamond (1989) dalam Sodik (2007) menyatakan bahwa pengeluaran sosial mempunyai hubungan positif yang signifikan kinerja keuangan.

Kinerja keuangan merupakan salah satu faktor yang dapat meningkatkan maupun menurunkan kesejahteraan masyarakat. Secara konsisten kinerja keuangan yang baik akan mendorong Indeks Pembangunan Manusia yang baik pula akan tetapi bila pertumbuhan ekonomi yang tinggi tidak di barengi dengan pembangunan manusia yang baik maka tidak akan berlangsung lama (sustainable). Agar berjalan positif dan berkelanjutan maka harus di dukung oleh kebijakan social yang pro pembangunan manusia. Belanja langsung dapat meningkatkan aktifitas masyarakat sehingga kinerja keuangan ikut meningkat. Kesejahteraan masyarakat dapat di tingkatkan oleh kinerja keuangan melalui belanja daerah. Berdasarkan hal tersebut maka hipotesis yang diajukan pada penelitian ini adalah.

$\mathrm{H}_{6}$ : Pertumbuhan ekonomi memediasi kinerja keuangan terhadap indeks pembangunan manusia.

Indeks pembangunan manusia merupakan ketidakmampuan memenuhi standar minimum kebutuhan dasar yang meliputi kebutuhan makan maupun non makan (BPS, 2008). Kemiskinan juga merupakan salah satu unsur suatu perekonomian yang sangat penting dan harus mendapat perhatian lebih dari pemerintah. Pertumbuhan ekonomi akan mempengaruhi tingkat kemiskinan suatu 
daerah, karena dengan meningkatnya pertumbuhan ekonomi, maka tingkat kemiskinan suatu daerah akan menurunkan.

Harianto dan Adi (2007) menunjukkan bahwa desentralisasi juga akan memberikan pengaruh bagi pertumbuhan ekonomi daerah. Pemberian otonomi yang lebih besar akan memberikan dampak yang lebih besar bagi pertumbuhan ekonomi. Hal inilah yang mendorong daerah untuk mengalokasikan secara lebih efisien berbagai potensi lokal untuk kepentingan pelayanan publik. Tersedianya infrastruktur yang baik diharapkan dapat menciptakan efisiensi dan efektivitas di berbagai sektor sehingga produktivitas masyarakat diharapkan menjadi semakin tinggi dan pada akhirnya terjadi peningkatan pertumbuhan ekonomi.

Hamzah (2008) dalam penelitiannya yang berjudul analisa kinerja keuangan terhadap pertumbuhan ekonomi, pengangguran dan kemiskinan menunjukkan bahwa variabel kinerja keuangan antara lain rasio kemandirian dan rasio efisiensi secara tidak langsung berpengaruh terhadap kemiskinan, sedangkan rasio efektivitas tidak berpengaruh terhadap kemiskinan. Berdasarkan uraian diatas, maka diajukan hipotesis sebagai berikut:

$\mathrm{H}_{7}$ : Pertumbuhan ekonomi memediasi kinerja keuangan terhadap indeks pembangunan manusia.

\section{METODE PENELITIAN}

Penelitian ini dilakukan pada Pemerintah Daerah Provinsi Bali. Jenis data yang digunakan dalam penelitian ini adalah data kuantitatif meliputi laporan realisasi anggaran, dan data mengenai PDRB tahun anggaran 2011-2015. Sumber data yang digunakan dalam penelitian ini adalah data sekunder. Data sekunder dalam penelitian ini diperoleh dari dinas atau instansi yang terkait, yaitu BPS dan Bagian 
Keuangan Provinsi Bali serta situs-situs Departemen Dalam Negeri dan Departemen Keuangan, beberapa laporan realisasi anggaran, data mengenai PDRB dan data kemiskinan tahun 2011-2015.

Populasi dalam penelitian ini adalah 8 Kabupaten dan 1 Kota di Provinsi Bali dari tahun 2011-2015. Metode penentuan sampel yang digunakan dalam penelitian ini adalah sampling jenuh yaitu teknik penentuan sampel bila semua anggota populasi digunakan sebagai sampel (Sugiyono, 2010:122). Jumlah kabupaten/kota dan provinsi sejumlah 9 dikalikan dengan jumlah tahun penelitian 2011 hingga tahun 2015. Total jumlah sampel adalah 45 sampel. Metode pengumpulan data yang digunakan dalam penelitian ini adalah metode observasi non partisipan, yaitu metode pengumpulan data dengan cara mengamati, mencatat,mempelajari uraian-uraian dari buku-buku, skripsi, artikel (Sugiyono, 2010:204), seperti dengan mengumpulkan data dari Biro Keuangan dan Badan Pusat Statistik (BPS) Provinsi Bali.

Teknik analisis data yang digunakan dalam penelitian ini adalah teknik analisis regresi linier berganda dengan bantuan Software Statistical Package for Social Science (SPSS) for Windows. Teknik analisis ini dipergunakan untuk melihat pengaruh kinerja keuangan terhadap pertumbuhan ekonomi, belanja daerah, dan indeks pembangunan manusia. Tahap analisis yang dilakukan adalah uji asumsi klasik, Analisis regresi linier berganda, analisis jalur (path analysis), adjusted $R^{2}$, uji kelayakan model (Uji F) dan uji hipotesis (Uji t). 


\section{HASIL DAN PEMBAHASAN}

Tabel 2 menunjukkan bahwa Mean variabel rasio kemandirian sebesar 11,11 persen dengan standar deviasi sebesar 16,62 persen. Rasio Kemandirian Pemerintah Daerah di Provinsi Bali per tahun yang terendah sebesar 1 persen dan yang tertinggi sebesar 58 persen. Mean variabel rasio pertumbuhan ekonomi sebesar 0,3769 dengan standar deviasi sebesar 1,521. Rasio Pertumbuhan ekonomi Pemerintah Daerah di Provinsi Bali per tahun yang terendah sebesar 0,89 dan yang tertinggi sebesar 10,14 persen. Mean variabel belanja daerah sebesar 11,55 dengan standar deviasi sebesar 0,3. Hal menunjukkan bahwa tingkat belanja daerah pada Pemerintah Daerah di Provinsi Bali masih pada tingkat yang rendah sekali. Belanja daerah pada Pemerintah Daerah di Provinsi Bali per tahun yang terendah 10,8 dan yang tertinggi sebesar 12,41. Mean variabel IPM sebesar 70,97 dengan standar deviasi sebesar 5,58. Hal menunjukkan bahwa tingkat kemiskinan pada Pemerintah Daerah di Provinsi Bali masih pada tingkat yang sedang. Tingkat IPM Pemerintah Daerah di Provinsi Bali per tahun dari yang terendah 61,6 dan yang tertinggi 82,2.

Tabel 2.

Statistik Deskriptif

\begin{tabular}{lcrrrr}
\hline & N & \multicolumn{1}{c}{ Minimum } & \multicolumn{1}{c}{ Maximum } & \multicolumn{1}{c}{ Mean } & \multicolumn{1}{c}{ Std. Deviation } \\
\hline Rasio & 45 &, 01 &, 58 &, 1111 &, 16628 \\
Kemandirian & & & & & \\
Pertumbuhan & 45 &,- 89 & 10,14 &, 3769 & 1,52138 \\
Ekonomi & & & & & \\
Belanja Daerah & 45 & 10,80 & 12,41 & 11,5558 &, 30037 \\
Indeks & 45 & 61,60 & 82,24 & 70,9698 & 5,58377 \\
$\quad$ Pembangunan & & & & & \\
$\quad$ Valid N (listwise) & 45 & & & & \\
Sumber: Data diolah, 2017 & & & &
\end{tabular}

Hasil uji normalitas menunjukkan nilai Asymp.Sig (2-tailed) dari uji normalitas adalah sebesar 0,$569 ; 0,316$ dan 0,988 lebih besar dari $\alpha=0,05$. Hal ini 
berarti model dalam penelitian ini berdistribusi normal. Hasil uji multikolinearitas menunjukkan bahwa koefisien tolerance dan VIF masing-masing variabel tidak mengalami gejala multikolinearitas. Hasil tersebut membuktikan bahwa tidak terdapat gejala multikolinearitas pada semua variabel bebas yang digunakan dalam penelitian ini. Hasil uji autokorelasi menunjukkan nilai D-W masingmasing persamaan sebesar 2,$073 ; 1,854$ dan 2,749 dengan nilai $4-\mathrm{d}_{\mathrm{L}}$ masingmasing sebesar 2,032; 1,362 dan 2,749 sedangkan nilai Du sebesar 1,615; 1,615 dan 1,720 . Oleh karena nilai $d$ statistic masing-masing persamaan berada diantara $\mathrm{d}_{\mathrm{U}}$ dan 4- $\mathrm{d}_{1}$ maka pengujian dengan Durbin-Watson berada pada daerah tidak ada autokorelasi maka ini berarti pada model regresi tidak terjadi gejala autokorelasi. Hasil uji heteroskedastisitas pada penelitian ini menunjukkan bahwa penelitian ini telah terbebas dari indikasi heteroskedastisitas karena tidak ada satupun nilai absolute residual variabel bebas yang berpengaruh signifikan $(>0,05)$ terhadap variabel terikat. Berdasarkan hasil tersebut dapat disimpulkan bahwa model regresi penelitian ini telah lolos uji asumsi klasik.

Tabel 3.

Fitness Model Test (Uji F)

\begin{tabular}{cc}
\hline Persamaan & Sig. \\
\hline 1 & 0,694 \\
2 & 0,000 \\
3 & 0,000 \\
\hline
\end{tabular}

Sumber: Data diolah, 2017

Analisis koefisien determinasi digunakan untuk mengukur seberapa besar variabel bebas mampu menjelaskan perubahan variabel terikatnya. Pada penelitian ini koefisien determinasi (Adjusted $R^{2}$ ) variabel bebas dalam model penelitian yang terlihat pada Tabel 3 menunjukkan ketiga persamaan tersebut layak uji. 
Tabel 4.

Fitness Model Test (Uji F)

\begin{tabular}{cc}
\hline Persamaan & R Square \\
\hline 1 & 0,004 \\
2 & 0,469 \\
3 & 0,491 \\
\hline
\end{tabular}

Sumber: Data diolah, 2017

Berdasarkan Tabel 4. dapat diketahui nilai $\mathrm{R}^{2}$ masing-masing persamaan sebesar 0,4 persen; 46,9 persen dan 49,1 persen yang berarti bahwa variasi perubahan pertumbuhan ekonomi, belanja daerah dan IPM dapat dijelaskan oleh variabel Kinerja Keuangan dan variabel interveningnya belanja daerah dan pertumbuhan ekonomi, sedangkan sisanya sebesar 99,6 persen; 55,1 persen dan 50,9 persen dipengaruhi oleh variabel lain di luar model.

Tabel 5.

Rangkuman Hasil Uji Regresi Linear Berganda

\begin{tabular}{|c|c|c|c|c|}
\hline \multicolumn{2}{|r|}{ Model } & Standardized Coefficient & \multirow{2}{*}{ Sig. } & \multirow{2}{*}{$\begin{array}{l}\text { Hasil Uji } \\
\text { Hipotesis }\end{array}$} \\
\hline Persamaan & Variabel & Beta & & \\
\hline 1 & Rasio Kemandirian & $-0,060$ & 0,694 & Ditolak \\
\hline \multirow[t]{2}{*}{2} & Rasio Kemandirian & 0,685 & 0,000 & Diterima \\
\hline & Rasio Kemandirian & 0,300 & 0,058 & Ditolak \\
\hline \multirow[t]{2}{*}{3} & Pertumbuhan Ekonomi & 0,226 & 0,815 & Ditolak \\
\hline & Belanja Daerah & 0,459 & 0,005 & Diterima \\
\hline
\end{tabular}

Sumber: Data diolah, 2017

Berdasarkan hasil analisis regresi linear berganda yang ditunjukan pada

Tabel 5, nilai koefisien $\mathrm{p}_{1}=-0,060$ menunjukkan bahwa jika kinerja keuangan daerah meningkat satu persen, maka pertumbuhan ekonomi menurun 6,0 persen dengan asumsi variabel independen lainnya konstan. Nilai koefisien $\mathrm{p}_{1}=0,685$ menunjukkan bahwa jika belanja daerah meningkat satu persen, maka rasio kemandirian akan meningkat sebesar 6,85 persen dengan asumsi variabel independen lainnya konstan. Nilai koefisien $\mathrm{p}_{1}=0,300$ menunjukkan bahwa jika rasio kemandirian meningkat satu persen, maka IPM akan meningkat sebesar 3,0 persen dengan asumsi variabel independen lainnya konstan. Nilai koefisien $\mathrm{p}_{2}=-$ 
0,226 menunjukkan bahwa jika pertumbuhan ekonomi meningkat satu persen, maka IPM akan menurun sebesar 22,6 persen dengan asumsi variabel independen lainnya konstan. Nilai koefisien $\mathrm{p}_{3}=0,459$ menunjukkan bahwa jika belanja daerah meningkat satu persen, maka IPM akan meningkat sebesar 45,9 persen dengan asumsi variabel independen lainnya konstan.

Hipotesis $\mathrm{H}_{1}$ menyatakan bahwa rasio kemandirian berpengaruh positif pada pertumbuhan ekonomi. Tingkat signifikansi $\alpha=0,05$ dan tingkat probabilitas (sig.) $\mathrm{t}$ variabel rasio kemandirian $=0,347>\alpha=0,005$ dengan nilai koefisien regresi bernilai negatif sebesar $(0,552)$. Kesimpulannya adalah rasio kemandirian tidak berpengaruh terhadap pertumbuhan ekonomi. Hipotesis $\mathrm{H}_{2}$ menyatakan bahwa rasio kemandirian berpengaruh positif pada IPM. Tingkat signifikansi $\alpha=$ 0,05 dan tingkat probabilitas (sig.) $\mathrm{t}$ variabel rasio kemandirian $=0,029<\alpha=$ 0,005. Kesimpulannya adalah rasio kemandirian berpengaruh positif terhadap IPM.

Hipotesis $\mathrm{H}_{3}$ menyatakan bahwa rasio kemandirian berpengaruh positif pada belanja daerah. Tingkat signifikansi $\alpha=0,05$ dan tingkat probabilitas (sig.) $\mathrm{t}$ variabel rasio kemandirian $=0,000<\alpha=0,005$ dan nilai koefisien regresi variabel rasio kemandirian bernilai positif sebesar $(1,238)$. Kesimpulannya adalah rasio kemandirian berpengaruh positif terhadap belanja daerah. Hipotesis $\mathrm{H}_{4}$ menyatakan bahwa pertumbuhan ekonomi berpengaruh positif pada IPM. Tingkat signifikansi $\alpha=0,05$ dan tingkat probabilitas (sig.) t variabel pertumbuhan ekonomi $=0,407>\alpha=0,005$ dan nilai koefisien regresi variabel rasio efisiensi bernilai positif sebesar (-0,096). Kesimpulannya adalah pertumbuhan ekonomi 
berpengaruh positif terhadap IPM. Hipotesis $\mathrm{H}_{5}$ menyatakan bahwa belanja daerah berpengaruh positif pada IPM. Tingkat signifikansi $\alpha=0,05$ dan tingkat probabilitas (sig.) t variabel belanja daerah $=0,0025<\alpha=0,005$ dan nilai koefisien regresi variabel rasio efisiensi bernilai positif sebesar $(8,535)$. Kesimpulannya adalah belanja daerah berpengaruh positif terhadap IPM.

Tabel 6.

\begin{tabular}{cccc}
\multicolumn{4}{c}{ Rangkuman Hasil Uji Mediasi } \\
\hline Pengaruh Variabel & $\begin{array}{c}\text { Pengaruh } \\
\text { Langsung }\end{array}$ & $\begin{array}{c}\text { Pengaruh Tidak } \\
\text { Langsung }\end{array}$ & Pengaruh Total \\
\hline $\mathrm{X}_{1} \rightarrow \mathrm{Y}_{1}$ & $-0,060$ & 0,053 & $-0,00318$ \\
$\mathrm{X}_{1} \rightarrow \mathrm{Y}_{3}$ & 0,300 & & \\
$\mathrm{Y}_{1} \rightarrow \mathrm{Y}_{3}$ & $-0,226$ & & \\
$\mathrm{X}_{1} \rightarrow \mathrm{Y}_{2}$ & 0,685 & 10,57 & 7,24045 \\
$\mathrm{X}_{1} \rightarrow \mathrm{Y}_{3}$ & 0,300 & & \\
$\mathrm{Y}_{2} \rightarrow \mathrm{Y}_{3}$ & 0,459 & & \\
\hline Sumber: Data diolah, 2017 & &
\end{tabular}

Sumber: Data diolah, 2017

Hasil tabel 6 menunjukkan bahwa variabel Pertumbuhan ekonomi tidak memiliki pengaruh signifikan terhadap Indeks Pembangunan Manusia. Hal ini menunjukkan bahwa variabel pertumbuhan ekonomi tidak mampu memediasi pengaruh variabel kinerja keuangan daerah terhadap Indeks Pembangunan Manusia. Hasil tabel 6 menunjukan bahwa belanja daerah berpengaruh positif terhadap Indeks Pembangunan Manusia dan variabel kinerja keuangan daerah berpengaruh terhadap Indeks Pembangunan Manusia. Hasil pengujian menunjukkan bahwa variabel belanja daerah merupakan variabel mediasi. Hasil pengujian pmediasi menunjukkan bahwa pengaruh total lebih besar dibandingkan pengaruh langsung antara kinerja keuangan daerah terhadap IPM (7,24045 > 0,300). Hasil tersebut menunjukkan bahwa variabel belanja daerah mampu memediasi hubungan antara variabel kinerja keuangan daerah terhadap Indeks Pembangunan Manusia. 
Berdasarkan hasil uji hipotesis yang telah dilakukan dapat diketahui Hipotesis pertama ditolak, dimana rasio kemandirian tidak berpengaruh signifikan terhadap pertumbuhan ekonomi. Ini berarti semakin tinggi rasio kemandirian tidak berpengaruh terhadap pertumbuhan ekonomi masing-masing kabupaten dan kota. Hasil penelitian sejalan dengan penelitian yang dilakukan Putri Ani (2012) yang menyimpulkan bahwa tidak terdapat pengaruh antara rasio kemandirian dan pertumbuhan ekonomi. Rasio kemandirian, yang menggambarkan kemampuan pemerintah daerah dalam mengelola dan membiayai pembangunan daerahnya masing-masing menunjukkan tidak adanya pengaruh secara statistik terhadap pertumbuhan ekonomi. Hal ini menunjukkan bahwa daerah belum mampu mengurangi ketergantungannya terhadap bantuan keuangan dari pemerintah pusat. Dengan belum mandiri suatu daerah tersebut, maka pertumbuhan ekonomi di daerah tersebut belum mengalami peningkatan yang signifikan.

Berdasarkan hasil uji hipotesis yang telah dilakukan dapat diketahui $\mathrm{H}_{2}$ diterima, dimana Rasio Kemandirian Berpengaruh positif terhadap Indeks Pembangunan Manusia. Ini berarti semakin tinggi rasio kemandirian semakin tinggi partisipasi masyarakat dalam membayar pajak dan retribusi daerah yang mana hal ini dapat meningkatkan Indeks Pembangunan Manusia. Hal ini mendukung penelitian oleh Putri Ani (2012) menunjukkan bahwa rasio kemandirian berpengaruh positif secara signifikan terhadap Indeks Pembangunan Manusia. Halim (2002) menyatakan semakin tinggi masyarakat membayar pajak dan retribusi daerah akan menggambarkan tingkat kesejahteraan masyarakat yang semakin tinggi. Masyarakat yang sudah mampu membayar pajak sesuai dengan 
Luh Dini Yasintha Dwiyandari dan I Dewa Nyoman Badera. Pengaruh ...

tingkat pendapatannya menunjukkan bahwa masyarakat sudah mandiri. Kemandirian masyarakat merupakan cerminan dari tingginya Indeks Pembangunan Manusia.

Berdasarkan hasil uji hipotesis yang telah dilakukan dapat diketahui bahwa rasio kemandirian berpengaruh terhadap belanja daerah. Hasil ini menerima $\mathrm{H}_{3}$ dimana rasio kemandirian berpengaruh pada belanja daerah. Hasil pengujian mendukung penelitian yang dilakukan oleh Bambang Prakosa (2004) yang menemukan bahwa rasio kemandirian berpengaruh secara signifikan terhadap belanja daerah. Kebijakan desentralisasi yang diterapkan selama ini terbukti dapat mewujudkan kemandirian daerah, sehingga kinerja daerah meningkat. Pemerintah Daerah mempunyai kewenangan untuk mengatur dan mengurus kepentingan masyarakat setempat menurut prakarsa sendiri berdasar aspirasi masyarakat (UU 32/2004). Kemampuan daerah untuk menyediakan pendanaan yang berasal dari daerah sangat tergantung pada kemampuan merealisasikan potensi ekonomi tersebut menjadi bentuk-bentuk kegiatan ekonomi yang mampu menciptakan perguliran dana untuk keperluan dana yang digunakan dalam belanja daerah.

Berdasarkan hasil uji hipotesis yang telah dilakukan dapat diketahui bahwa pertumbuhan ekonomi tidak berpengaruh terhadap Indeks Pembangunan Manusia. Hasil ini menolak $\mathrm{H}_{4}$ dimana pertumbuhan ekonomi berpengaruh positif pada Indeks Pembangunan Manusia. Hasil penelitian yang dilakukan oleh Susanti (2007) yang menemukan bahwa pertumbuhan ekonomi tidak berpengaruh signifikan terhadap Indeks Pembangunan Manusia. Hal ini dimungkinkan terjadi 
karena penerimaan daerah dari tahun ke tahun tidak terlalu tinggi, sehingga kurang mampu mendorong pengalokasian belanja modal yang digunakan untuk mengembangkan program-program dalam meningkatkan Indeks Pembangunan Manusia. Alokasi selama ini hanya lebih banyak pembangunan infrastruktur dan belanja pegawai.

Berdasarkan hasil uji hipotesis yang telah dilakukan dapat diketahui bahwa belanja daerah berpengaruh pada indeks pembangunan manusia. Hasil ini menerima $\mathrm{H}_{5}$ dimana belanja daerah berpengaruh positif pada indeks pembangunan manusia. Hasil ini mendukung penelitian yang dilakukan oleh Wongdesimiwati (2009) dan Saragih (2003), menemukan bahwa terdapat hubungan yang positif antara belanja daerah dan indeks pembangunan manusia. Kenaikan belanja daerah akan meningkatkan indeks pembangunan manusia. Daerah yang pertumbuhan ekonominya positif mempunyai kemungkinan mendapatkan kenaikan belanja daerah. Dari hasil pengujian ini menunjukkan bahwa pemda lebih berkonsentrasi pada pemberdayaan SDM yang pada akhirnya akan terjadinya peningkatan kualitas taraf hidup manusia (Adi, 2007). Peningkatan belanja daearah secara signifikan menunjukkan kemampuan daerah dalam memenuhi kebutuhannya serta memakmurkan masyarakatnya. Dengan meningkatnya aktivitas ekonomi melalui belanja daerah pada masyarakat, akan terjadi peningkatan jumlah output barang dan/ atau jasa yang diikuti pula dengan meningkatnya jumlah uang beredar dari segi pembelanjaan yang dilakukan oleh pemerintah daerah. 
Berdasarkan hasil uji pengaruh langsung dan tak langsung menunjukkan bahwa belanja daerah dapat memediasi pengaruh kinerja keuangan pada Indeks Pembangunan Manusia. Variabel belanja daerah mampu memediasi variabel kinerja keuangan daerah terhadap indeks pembangunan manusia. Hal ini dapat dilihat dari hasil pengujian yang menunjukkan bahwa belanja daerah berpengaruh langsung terhadap indeks pembangunan manusia, kinerja keuangan daerah berpengaruh terhadap indeks pembangunan manusia dan kinerja keuangan daerah berpengaruh terhadap belanja daerah sebagai syarat awal dalam menguji variabel mediasi.

Pengujian mediasi mensyaratkan pengaruh antara variabel independen berpengaruh terhadap variabel dependen, variabel dependen berpengaruh terhadap variabel mediasi dan variabel mediasi berpengaruh terhadap variabel independen. Hasil pengujian menunjukkan bahwa pengaruh kinerja keuangan daerah terhadap indeks pembangunan manusia menjadi semakin tinggi bila melalui belanja daerah. Daerah yang pertumbuhan ekonominya positif mempunyai kemungkinan mendapatkan kenaikan belanja daerah. Kenaikan belanja daerah yang alokasinya terfokus pada pemberdayaan SDM yang pada akhirnya akan terjadinya peningkatan kualitas taraf hidup manusia (Adi, 2007).

Berdasarkan hasil uji pengaruh langsung dan tak langsung menunjukkan bahwa pertumbuhan ekonomi tidak dapat memediasi pengaruh kinerja keuangan pada Indeks Pembangunan Manusia. Variabel pertumbuhan ekonomi bukan merupakan variabel mediasi. Hal ini dapat dilihat dari hasil pengujian yang menunjukkan bahwa pertumbuhan ekonomi tidak memiliki pengaruh terhadap 
Indeks Pembangunan Manusia, kinerja keuangan tidak berpengaruh terhadap pertumbuhan ekonomi. Hasil pengujian yang menunjukkan bahwa pengaruh antar variabel tidak ada yang signifikan maka pengujian mediasi tidak dapat dilakukan.

\section{SIMPULAN}

Berdasarkan hasil analisis dan pembahasan yang telah dilakukan maka dapat disimpulkan sebagai berikut: 1) Kinerja Keuangan Daerah tidak berpengaruh pada Pertumbuhan Ekonomi di Pemerintah Provinsi Bali; 2) Pertumbuhan Ekonomi tidak berpengaruh pada Indeks Pembangunan manusia di Pemerintah Provinsi Bali.; 3) Kinerja Keuangan Daerah berpengaruh positif pada Indeks Pembangunan Manusia di Pemerintah Provinsi Bali; 4) Kinerja Keuangan Daerah berpengaruh positif pada Belanja Daerah di Pemerintah Provinsi Bali; 5) Belanja Daerah berpengaruh positif pada Indeks Pembangunan Manusia di Pemerintah Provinsi Bali; 6) Pertumbuhan ekonomi tidak mampu memediasi pengaruh variabel kinerja keuangan terhadap Indeks Pembangunan Manusia. Variabel pertumbuhan ekonomi bukanlah merupakan variabel mediasi; 7) Belanja daerah mampu memediasi pengaruh variabel kinerja keuangan terhadap Indeks Pembangunan Manusia. Saran yang dapat direkomendasikan yaitu bagi penelitian selanjutnya, sebaiknya tidak menggunakan pertumbuhan ekonomi dan belanja daerah sebagai variabel mediasi dan mempertimbangkan variabel-variabel lain yang dimungkinkan lebih relevan dengan indeks pembangunan manusia.

\section{REFERENSI}

Adi, Priyo Hari. 2005. Dampak Desentralisasi Fiskal terhadap Pertumbuhan Ekonomi (Studi pada Kabupaten dan Kota Se Jawa Bali). Jurnal Studi Pembangunan Kritis. Universitas Kristen Satya Wacana. Salatiga. 
Darwanto dan Yustikasari. 2006. Pengaruh Pertumbuhan Ekonomi, Pendapatan Asli Daerah, dan Dana Alokasi Umum terhadap pengalokasian Anggaran Belanja Modal, Studi Kasus Kabupaten /Kota se-Jawa Bali tahun 20042005.

Erlis, Nola 2010, Pengaruh Pertumbuhan Ekonomi dan Sisa Pembiayaan Anggaran Terhadap Belanja Modal dengan Pendapatan Asli Daerah dan Dana Alokasi Pemekaran Daerah Pulau Sumatra. Jurnal Akuntansi, vol.53, pp: 89-98.

Faridi, Muhammad Zahir. 2011. Contribution of Fiscal Decentralization to Economic Growth: Evidence from Pakistan. Pakistan Journal of Social Sciences (PJSS)Vol. 31, No. 1 (June 2011), pp. 1-1.

Fidelius. 2013. Analisis Rasio untuk Mengukur Kinerja Pengelolaan keuangan daerah Kota Manado. Fakultas Ekonomi dan Bisnis, Universitas Sam Ratulangi. Mando.

Florida, Asha. 2006. Pengaruh Pendapatan asli Daerah (PAD) Terhadap Kinerja Keungan Pemerintah Kabupaten dan Kota di Provinsi Sumatra Utara. Tesis. Sekolah Pasca Sarjana Universitas Sumatra Utara.

Ghozali, Imam. 2011. Aplikasi Analisis Multivariate Dengan program SPSS. Semarang : BP Universitas Diponegoro.

Garita, Gus. 2009. How Does Financial Openess Affect Economic Growth and Its Components?. Institute For Monetary and Economic Research, The Bank Of Korea, 110, 3-Ga, and nendaemun-Ro, Jung-Gu, seoul 100-794, Korea.

Govinda Rao, M. 2003. Fiscal Decentralization In China And India: A Comparative Perpspective. Asia-Pacific Development Journal. Vol. 10, No. 1, June 2003.

Halim, Abdul. 2007. Akuntansi Sektor Publik Akuntansi Keuangan Daerah. Edisi Ke-3. Jakarta: Salemba Empat.

Hamzah, Ardi. 2007. Analisa Kinerja Keuangan Terhadap Pertumbuhan Ekonomi, Pengangguran, dan Kemiskinan: Pendekatan Analisis Jalur (studi pada 29 Kabupaten dan 9 Kota di Propinsi Jawa Timur periode 2001-2006). Jurnal Akuntansi.

Harianto, David dan Priyo Hari Adi. 2007. Hubungan Antara Dana Alokasi Umum, Belanja modal, Pendapatan Asli Daerah, dan Pendapatan per Kapita. Simposium Nasional Akuntansi X.

Irawan, Arief Wahyu. 2013. Analisa Pengaruh Kinerja Keuangan Daerah Terhadap Tingkat Pertumbuhan Ekonomi, Pengangguran, dan Kemiskinan (studi kasus pada seluruh kabupaten se Jawa Tengah periode 2007-2009). 
Universitas Muhammadiyah Purwokerto. Jurnal Studi Akuntansi, vol.45, pp:55-61.

Jalil, Abdula dan Ma Ying. 2008. Financial Developmen, Economic Growth and Adaptive Efficiency: A Comparison Between China and Pakistan. China \& World Economy, 16(6): h: 97-111, November-December 2008.

John Bohte and Kenneth J. Meier. 2000. "The Marble Cake: Introducing Federalism to the Government Growth Equation." Publius: The Journal of Federalism.

Khusaini, Muhammad Dr. 2006. Ekonomi Publik: Desentralisasi Fiskal dan Pembangunan Daerah, BPFE Unibraw.

Kristanto, Didin. 2014. Analisis Kinerja Keuangan Pemerintah Daerah Kabupaten Klaten Dilihat Dari Pendapatan Daerah Pada APBD 2010-2012. Universitas Muhammadiyah Surakarta.

Kurniati, Siti. Analisis Perbandingan Kinerja Keuangan Pemerintah Daerah Kabupaten Kota Se-Jawa Tengah Sebelum dan Sesudah Krisis Ekonomi 2008. Fakultas Ekonomi dan Bisnis Universitas Diponegoro. Semarang.

Mahmood-ul-hassan and Shahzad Hussain. Fiscal Decentralization and Economic Growth In Pakistan. Bahauddin Zakariya University, Multan, Pakistan.

Mahmudi (2010), Manajemen Kinerja Sektor Publik, Edisi Kedua, UPP STIM $Y K P N$, Yogyakarta.

Manik, Tumpal 2013. Analisis Pengaruh Kemakmuran, Ukuran Pemrintah Daerah, inflasi, Intergovernmental Revenue dan Kemiskinan Terhadap Pembangunan Manusia dsn Pertumbuhan Ekonomi. Universitas Maritim Raja Ali Haji (UMRAH).

Mochamad Rizky Azzumar, 2011. Pengaruh Pendapatan Asli Daerah, Dana Perimbangan, Investasi Swasta, Tenaga Kerja Terhadap Pertumbuhan Ekonomi Di Era Desentralisasi Fiskal Tahun 2005-2009 (Studi Kasus Kabupaten/Kota Provinsi Jawa Tengah).

Mulyono. 2012. The Impact of fiscal Decentralization on Regional Economic Development in Indonesia For the Periods 2005-2008. Ritsumeikan Asia Pasific University, International Cooperation Policy. Determinasi

Pramono, Joko. 2014. Analisis Rasio Keuangan untuk Menilai Kinerja Keuangan Pemerintah Daerah (studi kasus pada pemerintah Kota Surakarta). STIE AMA Salatiga. Jurnal Akuntansi 
Pusparini, Riza. 2012. Pengaruh Analisis Kinerja Keuangan Pemerintah Daerah Terhadap Pertumbuhan Ekonomi, Pengangguran dan Kemiskinan. Fakultas Ekonomi, Universitas Islam Indonesia. Yogyakarta. Jurnal Akuntansi, Vol.34, pp:61-64

Putri Ani. 2012 . Pengaruh Kinerja Keuangan Daerah Pada Pertumbuhan Ekonomi, Pengangguran, dan Kemiskinan di Kabupaten/Kota Provinsi Bali. Fakultas Ekonomi dan Bisnis, Universitas Udayana. Bali. Jurnal Akuntansi, Vol. 12, pp: 34-45.

Rizkiano, Aswin. Pengukuran Tingkat Kemampuan Keuangan Daerah Dalam Mendukung Pelaksanaan Otonomi Daerah Periode 2004-2008 di Kota Salatiga. Fakultas Ekonomi Universitas Diponegoro. Semarang. Jurnal Akuntansi, Vol. 16, pp:20-25

Restianto, Yanuar E dan Sularso, Havid. Pengaruh Kinerja Keuangan Terhadap Alokasi Belanja Modal dan Pertumbuhan Ekonomi Kabupaten/Kota di Jawa Tengah. Fakultas Ekonomi Universitas Jenderal Sudirman. Purwokerto. Jurnal Akuntansi.

Seftarita, Chenny. 2005. Kebijakan Fiskal, Kebijakan Moneter, dan Pertumbuhan Ekonomi di Indonesia. Simposium Riset Ekonomi II. Surabaya.

Setyanda, Hanika. Analisis Kinerja Keuangan terhadap Pertumbuhan Ekonomi, Pengangguran dan Kemiskinan Pendekatan analisis jalur (Studi pada Kab/Kota di Provinsi D.I. Yogyakarta). Fakultas Ekonomi, Universitas Muhammadiyah. Yogyakarta. Jurnal Ekonomi Pembangunan.

Sholikhah, Ratna. 2011. Analisis Kemampuan Kemandirian Keuangan Daerah dan Pengaruhnya Terhadap Pertumbuhan Ekonomi Kabupaten Wonogiri Tahun Anggaran 2002-2009. Universitas Sebelas Maret Surakarta.

Sugiyono. 2010.Metode Penelitian Bisnis.Bandung: Alfabeta.

Yuana, Putri. 2014. Analisis Kinerja Keuangan Daerah Terhadap Pertumbuhan Ekonomi Dan Ketimpangan Regional Di Era Desentralisasi Fiskal (Studi Kabupaten/Kota Di Provinsi Jawa Timur Periode 2008-2012). Fakultas Ekonomi dan Bisnis, Universitas Brawijaya. Malang. 